\title{
Epilithic communities in a lake littoral zone: the role of water-column transport and habitat development for dispersal and colonization of meiofauna
}

\author{
Lars Peters ${ }^{1}$ \\ Limnological Institute, University of Konstanz, D-78457 Konstanz, Germany \\ Markus A. Wetzel ${ }^{2}$ \\ Department of Animal Ecology, German Federal Institute of Hydrology, D-56002 Koblenz, Germany \\ Walter Traunspurger ${ }^{3}$ \\ Animal Ecology, University Bielefeld, Morgenbreede 45, D-33615 Bielefeld, Germany \\ Karl-Otto Rothhaupt ${ }^{4}$ \\ Limnological Institute, University of Konstanz, D-78457 Konstanz, Germany
}

\begin{abstract}
During the past $30 \mathrm{y}$, periphyton has been recognized as a key component in the benthos of lake littoral zones. However, the role of meiofauna-sized organisms living in the periphyton and mechanisms regulating and influencing those communities largely have been neglected, and the process of community development and colonization pathways of periphytic meiofauna are unknown in lakes. We studied these processes on littoral hard substrates in an oligotrophic lake. We manipulated the access of meiofauna to artificial hard substrates for a period of $57 \mathrm{~d}$ in a field experiment. In one treatment, the direct colonization pathway via active crawling was prohibited by elevating substrates into the water column. Development of the meiofaunal community was compared between elevated and nonelevated (control) treatments. In addition, relationships among the meiofaunal communities on the substrates in the field experiment and those in sediment traps and on natural hard substrates were examined. Periphyton biomass (chlorophyll $a$, total organic matter) and inorganic matter increased significantly in both experimental treatments throughout the experiment. Meiofauna colonized the substrates quickly and reached maximum densities of 107 ind. $/ \mathrm{cm}^{2}$. The initial colonization phase (2-8 d) was characterized by a great variation in meiofaunal community structure; rotifers and crustaceans were the most abundant groups. Communities became less variable during the experiment and resembled natural communities on hard substrates at the end of the experiment. In general, development of meiofaunal abundance and periphyton biomass was rapid and proceeded similarly in both treatments. Our results show that colonization of littoral hard substrates can be driven by water-column transport of meiofauna and point to the importance of this pathway for dispersal and colonization of hard substrates by meiofauna.
\end{abstract}

Key words: epilithon, habitat structure, meiobenthos, nematodes, passive transport, periphyton, rotifers.

During the past 2 decades, meiofauna organisms has been shown to be rapid colonizers of benthic commu-

\footnotetext{
${ }^{1}$ Present address: Animal Ecology, University Bielefeld, Morgenbreede 45, D-33615 Bielefeld, Germany. E-mail: lars.peters@uni-bielefeld.de

2 E-mail addresses: markus.wetzel@bafg.de

3 traunspurger@uni-bielefeld.de

4 karl.rothhaupt@uni-konstanz.de
}

nities (Palmer 1988, Boulton et al. 1991, Palmer et al. 1992, Atilla and Fleeger 2000, Wetzel et al. 2002) even though permanent meiofauna lack pelagic larvae. The within-habitat dispersal of such organisms is thought to be driven by passive transport through the water column (Hagerman and Rieger 1981, Palmer 1988, Atilla and Fleeger 2000, Robertson 2002), but several authors have reported dispersal by active movement of 
these organisms (Jensen 1981, Palmer et al. 1992, Robertson 2000, Duft et al. 2002, Ullberg and Ólafsson 2003). Benthic recolonization experiments have shown that copepods typically are among the first settlers because of their better swimming ability as compared to other meiofaunal organisms such as nematodes (Fegley 1988, Sun and Fleeger 1994). In contrast, other studies revealed that nematodes also are rapid colonizers, capable of reaching abundances found in undisturbed samples within 1 to 2 d (Sherman and Coull 1980, Colangelo and Ceccherelli 1994). Some authors reported that those meiofaunal organisms living closest to the water-substrate interface have the highest risk of being eroded from the substrates into the water column (Warwick and Gee 1984, Eskin and Palmer 1985, Palmer and Gust 1985), and that if meiofaunal organisms are suspended in the water column, water movement plays an important role in the dispersal of the organisms (Sherman and Coull 1980, Palmer 1988).

Many of these studies were conducted in marine environments, and nearly all studies of colonization abilities, including those of freshwater meiofauna, have focused on soft-sediment habitats. The few studies that have investigated meiofauna in the epilithic periphyton (benthic communities on rock substrates) generally reported a numerically abundant community with diverse species (Traunspurger 1992, Peters and Traunspurger 2005). However, the pool of available information about such organisms is too small for us to understand their functional role within littoral ecosystems. To date, the processes of community development and the colonization pathways of epilithic meiofauna are unknown. This absence of information is surprising because periphyton is considered a key component of ecosystems in shallow littoral zones of lakes and streams. It is an important source of primary production (e.g., Vadeboncoeur and Steinman 2002) and a food resource (e.g., Feminella and Hawkins 1995, Hillebrand 2002). Moreover, the development of epilithic communities (excluding meiofauna) by autotrophic and heterotrophic microorganisms has been well studied (e.g., Dickman 1974, Hoagland et al. 1982, Johnson et al. 1997).

The littoral zones of lakes often are subject to dramatic changes in habitat structure because of periodic disturbances, e.g., storm/wind events, wave action, or water-level fluctuations. This hydrodynamic stress often leads to large-scale changes in the composition of benthic communities (Connell and Slatyer 1977, Picket and White 1985, Witthöft-Mühlmann et al. 2005) or can remove most of the organisms from substrates (Barton and Carter 1982, Hoagland 1983, Dall et al. 1984, Roemer et al. 1984, Hoagland et al. 1986). Studies on the effect of disturbance on periphyton in lakes have shown that wind-induced wave action can detach parts of the attached community and decrease epilithic biomass (Young 1945, Kairesalo 1976, 1983, Hoagland et al. 1986). Such removal leads to new space availability for colonization. Organisms living on littoral hard substrates in lakes have to cope with these conditions and respond quickly to continuous or short-time disturbance events. If space for colonization is available after disturbance, the ability to colonize quickly and to persist on colonized substrates is important for successful establishment of a new population. Hoagland et al. (1986) investigated the source of algal colonizers (particularly diatoms) and compared diatom sedimentation from the water column with direct, horizontal movement as a colonization mode in an impoundment reservoir. They found that sedimentation of algal cells was much more important for the colonization of littoral hard substrates than direct movement from adjacent attached communities.

Our knowledge of the effects of such processes on organisms living in the periphyton on hard substrates in littoral zones of lakes is still limited. Colonization patterns on hard substrates cannot be inferred easily from colonization of soft sediments because these habitats differ greatly in structure and complexity. Soft sediments offer space for colonization in an alwayspresent, complex, 3-dimensional structure, and therefore, colonization can begin immediately after a disturbance, leading to natural densities of meiofauna even within hours (Sherman et al. 1983). In contrast, more-or-less bare hard substrates do not offer such a complex habitat structure during the initial stages of colonization, and therefore, more time will be required to reach natural meiofaunal densities. The ongoing temporal development of a complex periphyton structure by colonization and growth of algae and heterotrophic microorganisms and by accumulation of detritus probably paves the way for meiofauna and might be viewed as a required facilitation process for meiofauna by providing habitat and resource simultaneously.

We conducted a field experiment in the littoral zone of Lake Constance to examine how periphyton biomass accumulation (i.e., habitat size and structure) and water-column dispersal affected the development of an epilithic meiofaunal community. This large lake is characterized by large water-level fluctuations throughout the year (usually $\sim 150 \mathrm{~cm}$ ) (Bäuerle et al. 1998) that cause extensive drying of littoral areas during winter. Substrates in the upper part of the littoral zone are only temporarily flooded during summer and are recolonized anew each spring with increasing water level. We prevented direct active 
colonization of artificial hard substrates by crawling meiofauna (e.g., nematodes or tardigrades) by elevating substrates in the water column during a 57-d period. Development of the meiofaunal community was then followed on both elevated and on nonelevated (control) substrates. Meiofaunal communities on these experimental substrates were compared with meiofaunal communities on natural hard substrates and in sediment traps. In addition, changes in species diversity on hard substrates were determined for nematodes. The answers to 4 principal questions were sought: 1) Is water-column dispersal the basic colonization pathway for epilithic meiofauna, as shown for soft-bottom meiofauna and algae? 2) If so, what is the correspondence between meiofauna in the water column and on the natural surrounding hard substrates? 3) Do meiofaunal organisms respond to changes in periphyton biomass during periphyton development? 4) How does meiofaunal group and nematode species composition change during periphyton development?

\section{Methods}

\section{Study site}

The study was conducted in spring (March-May) 2003 in the littoral zone of Lower Lake Constance, 1 basin in a prealpine meso-oligotrophic lake in central Europe. Lower Lake Constance covers an area of 71.5 $\mathrm{km}^{2}$ with a mean depth of $13.2 \mathrm{~m}$. The littoral zone of the lake is characterized by large areas of cobblestones of different size and water-level fluctuations of up to $150 \mathrm{~cm}$ throughout the year, with highest water levels in June/July (beginning of summer) and lowest levels in February/March (end of winter). The experimental site (lat $47^{\circ} 41.10^{\prime} \mathrm{N}$, long $9^{\circ} 04.19^{\prime} \mathrm{E}$ ) is influenced by westerly winds.

\section{Experimental setup and sampling}

Artificial substrates for 2 treatments were placed in the littoral zone at depths between $60 \mathrm{~cm}$ and $80 \mathrm{~cm}$. Substrates consisted of an aluminum plate $(50 \times 50 \mathrm{~cm})$ with indentations for 8 unglazed ceramic tiles $(4.7 \times$ $4.7 \mathrm{~cm}$ ). Such tiles were used successfully in other studies on periphyton (Hillebrand and Kahlert 2001, Hillebrand et al. 2002, Peters et al. 2007). The 2 treatments differed in the placement of the aluminum plates, which were placed either directly on the bottom (control) or $30 \mathrm{~cm}$ above the bottom (elevated) using four $30-\mathrm{cm}$-long aluminum legs. Elevated substrates could not be colonized directly by meiofauna that crawl along the bottom. Substrates in the 2 treatments were placed at random locations near each other, and each treatment was replicated 4 times. Such an experimental design was used successfully in macrograzer-exclusion experiments in streams (Lamberti and Resh 1983, Lamberti et al. 1992), and therefore, was considered appropriate for testing our hypotheses for less mobile meiofaunal organisms. The experiment began on 12 March 2003, and 1 randomly selected tile was sampled from each experimental substrate after 2, $4,6,8,15,22,29$, and $57 \mathrm{~d}$ (8 May 2003). Sampled tiles were carefully transferred underwater into plastic boxes and stored in the dark until processed in the laboratory $(<3 \mathrm{~h})$.

Organisms on natural hard substrates were sampled using a brush sampler (Peters et al. 2005a). This syringe-like sampler scrapes a defined circular area $\left(3.14 \mathrm{~cm}^{2}\right)$ on hard substrates and collects all sampled material without loss or contamination. Three replicate stones near the experimental substrates were sampled on the same dates as described above. Two brushsamples were taken from each stone and were pooled (total sample area $=6.28 \mathrm{~cm}^{2}$ ) to yield adequate amounts of material and to minimize the effects of small-scale heterogeneity in the periphyton. These samples were stored as described above until processed in the laboratory.

Meiofaunal sedimentation rates were measured using 3 cylindrical sediment traps (Gardner 1979a, b) placed $\sim 2 \mathrm{~m}$ from the experimental substrates. Each trap consisted of a Perspex cylinder (60-mm inner diameter, 16-cm height) with a screwed-on 100-mL polyethylene bottle as a collector. The traps had an overall height of $30 \mathrm{~cm}$ above the lake bottom, similar to the height of the elevated substrates. Traps and treatments were sampled on the same days, and trap samples were stored as described above.

\section{Sample preparation and analysis}

In the laboratory, all epilithic material was carefully removed from the tiles using filtered lake water and a razor blade, and algal conglomerates were carefully separated with scissors and forceps. The suspension was adjusted to a defined volume $(100 \mathrm{~mL})$. Two 10$\mathrm{mL}$ aliquots of this suspension were filtered onto glassfiber filters (Schleicher and Schuell GF6, Ø $25 \mathrm{~mm}$ ) for analysis of organic and inorganic matter (ash-free dry mass, using precombusted filters) and for chlorophyll $a$ determination. Samples on filters for chlorophyll $a$ determination were stored frozen at $-20^{\circ} \mathrm{C}$ until analyzed. For meiofaunal determination, $70 \mathrm{~mL}$ of each sample suspension was sieved through a $30-\mu \mathrm{m}-$ mesh net, and the contents of the net were fixed with formaldehyde (4\% final concentration) and stained with rose Bengal $(300 \mu \mathrm{g} / \mathrm{mL})$. 
Samples from the sediment traps were adjusted to $200-\mathrm{mL}$ volume. For meiofaunal determination, $20 \mathrm{~mL}$ of each sample was sieved through a $30-\mu \mathrm{m}$-mesh net, and the contents of the net were fixed and stained as described above.

Brush samples from natural hard substrates were adjusted to a defined volume (100-125 mL). Two 10$\mathrm{mL}$ aliquots were filtered as described above for chlorophyll $a$ and ash-free dry mass determination. The remainder (70-95 mL) of the sample was fixed for meiofaunal determination as described above.

Chlorophyll $a$ was analyzed using the method described by Marker et al. (1980) and Nusch (1980). Briefly, chlorophyll $a$ was extracted with $90 \%$ ethanol and was measured spectrophotometrically; pheophytin-uncorrected values were used to calculate chlorophyll a concentrations (Stich and Brinker 2005). Organic and inorganic components were determined by measuring the ash-free dry mass. The filters were dried at $105^{\circ} \mathrm{C}$ for $24 \mathrm{~h}$, followed by combustion at $550^{\circ} \mathrm{C}$ for $5 \mathrm{~h}$.

All meiofaunal organisms were counted and classified into taxonomic groups (nematodes, rotifers, crustaceans [copepods and ostracods], and others [oligochaetes and tardigrades]) using a stereomicroscope at $40 \times$. When possible, 50 nematodes/replicate were isolated using a stereomicroscope, transferred to glycerol solution (Seinhorst 1959, 1962), mounted on slides, and identified to the species level using a Leitz Dialux microscope at $1250 \times$.

\section{Statistical analyses}

Differences in periphyton biomass (chlorophyll $a$, organic and inorganic matter content) and meiofaunal abundance between treatments (control and elevated substrates) with time (day 2-57) were analyzed by repeated-measures analysis of variance (ANOVA) using Statistica software (version 6; StatSoft, Tulsa, Oklahoma). $\log _{\mathrm{e}}(\mathrm{x})$-transformed biomass data (chlorophyll $a$, organic and inorganic matter) and untransformed meiofaunal abundance data were homoscedastic. Species diversity was measured as species richness (number of species/sample), Shannon-Wiener diversity $\left(\mathrm{H}^{\prime} ; \log _{2}\right)$, and Pielou's evenness $\left(\mathrm{J}^{\prime}\right)$.

Meiofauna analyses were carried out using the PRIMER software package (version 6; PRIMER-E, Plymouth, UK). Nonmetric multidimensional scaling (NMDS) and analysis of similarities (ANOSIM) was applied to meiofaunal groups to identify differences in group composition and the development of meiofauna between experimental treatments and sampling days. The Bray-Curtis coefficient $(S)$ was used for comput- ing similarities based on absolute group abundance (ind. $/ \mathrm{cm}^{2}$ ). Meiofaunal abundance data were $V(x)$ transformed before calculating Bray-Curtis similarities. $S$ has the advantage of being uninfluenced by joint absences of species in 2 samples, a circumstance under which many other coefficients fail (Clarke and Green 1988). The quality or reliability of a 2-dimensional NMDS plot is indicated by the stress value, which gives good or excellent representation of the similarities between samples when the stress value is $<0.1$ or $<0.05$, respectively (Clarke 1993).

The ANOSIM procedure compares the ranked similarities of differences within and between groups. A large $R$ value close to 1 indicates separation of the groups, and small values close to 0 imply little or no separation (Clarke and Warwick 2001). In contrast to standard Z-type statistics, an absolute interpretation of values of $R$ is potentially more meaningful than its statistical significance. As with standard tests, $R$ can be significantly different from 0 with a difference too small to be important. $R$ can be computed globally in a manner analogous to the procedure ( $F$-value calculation) in an ANOVA test and for pairwise comparisons based on multiple post-hoc tests. We considered $R$ values $>0.5$ to indicate pronounced differences between groups.

The RELATE procedure in PRIMER was used to test for linear seriation patterns (index of multivariate seriation [IMS]) in the temporal development of the meiofaunal communities. The IMS takes values $(\rho)$ of 1 if changes in the community structure exactly match a linear sequence (i.e., a successive temporal community development toward climax state) and will be close to 0 when there is no perceptible biotic pattern to the temporal change (Clarke et al. 1993). NMDS, ANOSIM, and RELATE calculations were based on BrayCurtis similarity using $\sqrt{ }(\mathrm{x})$-transformed group abundance (ind. $/ \mathrm{cm}^{2}$ ) data.

\section{Results}

\section{Periphyton biomass}

Periphyton biomass (chlorophyll $a$, organic and inorganic matter content) showed a significant temporal increase in both treatments (Table 1; Fig. 1A-C). Throughout the 57-d colonization period, chlorophyll $a$ and organic matter contents increased $\sim 25$-fold and $\sim 13$-fold, respectively, and no significant differences between the 2 treatments were detected (Table 1). Inorganic matter content showed similar patterns and increased significantly from $0.6 \mathrm{mg} / \mathrm{cm}^{2}$ to $41.4 \mathrm{mg} /$ $\mathrm{cm}^{2}$ on control substrates and from $0.4 \mathrm{mg} / \mathrm{cm}^{2}$ to 23 $\mathrm{mg} / \mathrm{cm}^{2}$ on elevated substrates. 
TABLE 1. Results of repeated-measures analysis of variance for effects of mode of colonization (elevated vs control treatments) and time on $\log _{\mathrm{e}}(\mathrm{x})$-transformed biomass variables and untransformed meiofaunal abundance.

\begin{tabular}{|c|c|c|c|c|c|c|c|c|c|c|c|c|c|c|c|c|}
\hline \multirow[b]{2}{*}{ Effects } & \multicolumn{4}{|c|}{ Chlorophyll $a$} & \multicolumn{4}{|c|}{ Organic matter } & \multicolumn{4}{|c|}{ Inorganic matter } & \multicolumn{4}{|c|}{ Meiofauna } \\
\hline & $\mathrm{df}$ & MS & $F$ & $p$ & $\mathrm{df}$ & MS & $F$ & $p$ & $\mathrm{df}$ & MS & $F$ & $p$ & $\mathrm{df}$ & MS & $F$ & $p$ \\
\hline \multicolumn{17}{|l|}{ Between subjects } \\
\hline $\begin{array}{l}\text { Treatment } \\
\text { Error }\end{array}$ & $\begin{array}{l}1 \\
6\end{array}$ & $\begin{array}{l}0.44 \\
0.08\end{array}$ & 5.36 & 0.06 & $\begin{array}{l}1 \\
5\end{array}$ & $\begin{array}{l}0.28 \\
0.13\end{array}$ & 2.11 & 0.21 & $\begin{array}{l}1 \\
5\end{array}$ & $\begin{array}{l}0.27 \\
0.14\end{array}$ & 1.95 & 0.22 & $\begin{array}{l}1 \\
6\end{array}$ & $\begin{array}{r}95.7 \\
181.0\end{array}$ & 0.53 & 0.49 \\
\hline \multicolumn{17}{|l|}{ Within subjects } \\
\hline Time & 7 & 7.45 & 129.55 & $<0.001$ & 7 & 5.25 & 29.01 & $<0.001$ & 7 & 11.35 & 143.81 & $<0.001$ & 7 & 11853.1 & 29.67 & $<0.001$ \\
\hline Time $\times$ treatment & 7 & 0.06 & 1.02 & 0.43 & 7 & 0.14 & 0.76 & 0.63 & 7 & 0.08 & 1.01 & 0.44 & 7 & 691.1 & 1.73 & 0.13 \\
\hline Error & 42 & 0.06 & & & 35 & 0.18 & & & 35 & 0.08 & & & 42 & 399.5 & & \\
\hline
\end{tabular}

\section{Meiofaunal abundance and community structure}

Meiofaunal abundance followed the pattern observed with periphyton biomass and increased significantly throughout the experiment in both treatments, which did not differ significantly from each other (Table 1; Fig. 2A). Rotifers were numerically dominant in both treatments in the initial 4-wk colonization stage. The relative abundance of crustaceans, the $2^{\text {nd }}$ most frequent group, fluctuated greatly in both treatments. Crustacean abundance reached a peak in $8 \mathrm{~d}$, decreased, and then increased to a maximum at the end of the experiment (Fig. 2B, C). The relative abundances of nematodes and others (mainly oligochaetes) increased constantly in both treatments, but their contribution to the overall meiofaunal abundance was low. Meiofaunal abundance and periphyton biomass (a measure of habitat size) were positively correlated in both treatments (Spearman rank correlation, chlorophyll $a$ vs meiofauna, $n=32$; elevated plates: $r=0.92, p<0.001$; control plates: $r=0.93, p<$ 0.001 ).

Meiofaunal community structure (group composition) was similar in both treatments (ANOSIM, $R=$ $0.322, p<0.001$ ). Group composition varied greatly among samples in the first $4 \mathrm{~d}$ of colonization in both treatments (Fig. 3). As colonization continued, group composition showed temporal development, i.e., group composition differed significantly between successive sampling dates (ANOSIM, $R=0.712, p<$ 0.001; Table 2), and variation among replicate samples within dates decreased (Fig. 3). Tests for a linear change in group composition through time were highly significant for control and elevated treatments (RELATE; control: $\rho=0.743, p<0.001$; elevated: $\rho=$ $0.801, p<0.001)$. Communities in both treatments nearly conformed to natural group composition after 57 d (Fig. 3).
Species pool on natural substrata and in sedimentation samples

The abundance of meiofaunal organisms on ambient hard substrates varied greatly throughout the experiment (Fig. 4A). Mean total meiofaunal abundance ranged from 151 ind. $/ \mathrm{cm}^{2}$ to $681 \mathrm{ind} . / \mathrm{cm}^{2}$. Rotifer relative abundance increased during the first $2 \mathrm{wk}$ of the experiment until they were the most abundant group and decreased after day 29 (Fig. 4C). Nematodes were the $2^{\text {nd }}$-most abundant group until day 29; on day 57, nematodes were as abundant as rotifers, followed by crustaceans and others.

Sedimentation rates of meiofaunal organisms varied greatly between sampling dates and were highest during the first $2 \mathrm{wk}$ of the experiment. Sedimentation rates ranged from 257 ind. $\mathrm{cm}^{-2} \mathrm{~d}^{-1}$ on day 8 to 6 ind. $\mathrm{cm}^{-2} \mathrm{~d}^{-1}$ on day 57 (Fig. 4B). Meiofaunal group composition in the sediment traps mirrored group composition on ambient hard substrates, i.e., maximum abundance of rotifers generally occurred between days 15 and 30 (Fig. 4D). Meiofaunal sedimentation was positively correlated with meiofaunal abundance on ambient hard substrates (Spearman rank correlation, $r=0.76, p<0.05, n=8$ ). Nematodes were the $2^{\text {nd }}$-most frequent group in the traps, followed by crustaceans and others. On day 57, nematodes were the numerically dominant group and constituted $68 \%$ of all meiofaunal organisms in the traps.

\section{Diversity of nematodes}

The initial colonization by nematodes was characterized by a large variation in abundance and species composition among the replicates of the 2 treatments. No nematodes were found on 2 of 4 replicates on day 2 in the control treatments and on days 2, 4, and 6 in the elevated treatments. A total of 22 and 17 species were found on the control and elevated treatments, respec- 

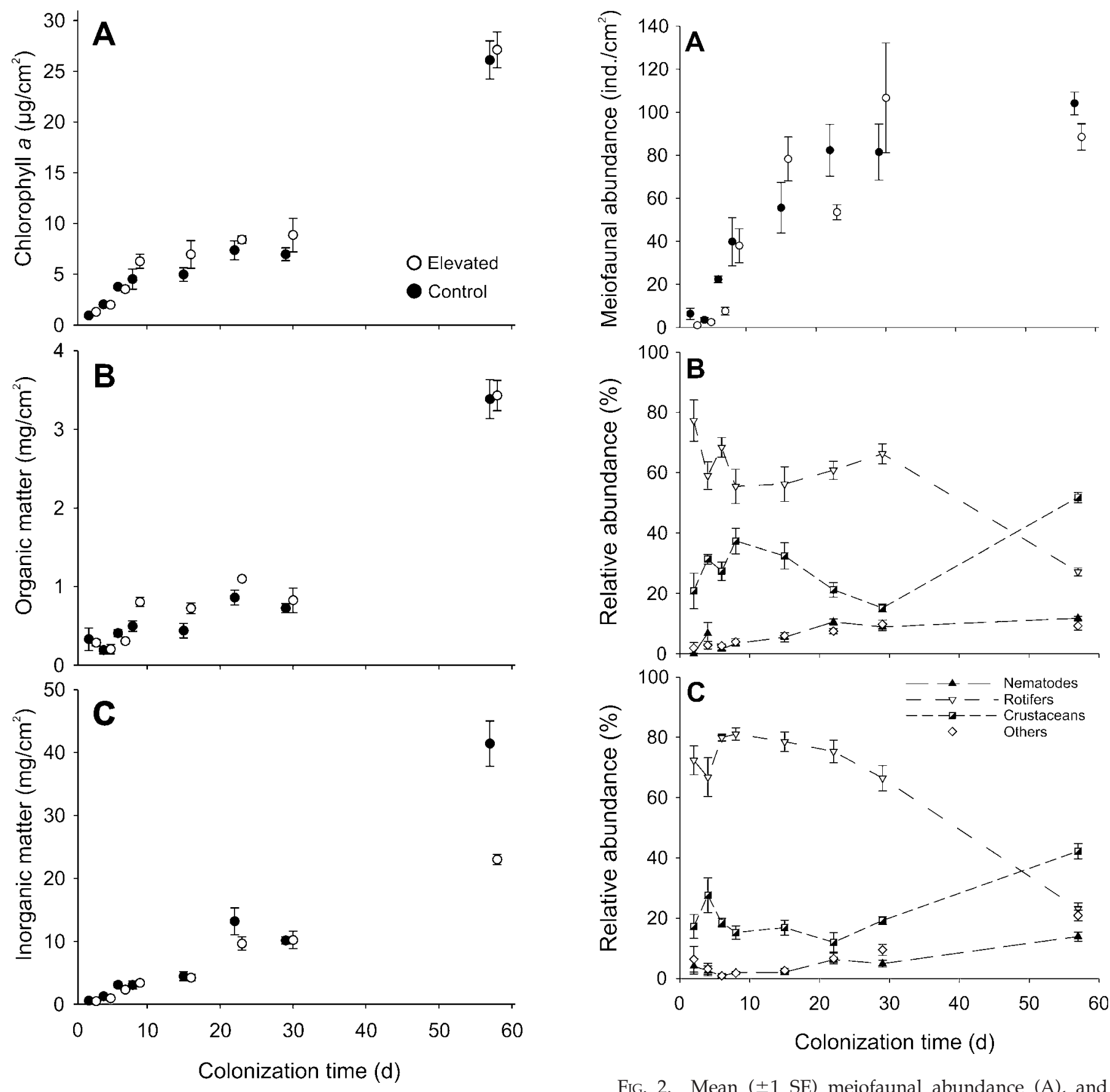

FIG. 1. Mean ( $\pm 1 \mathrm{SE}$ ) algal biomass (chlorophyll a) (A), organic matter content (B), and inorganic matter content (C) on elevated and control experimental substrates after 2, 4, 6, $8,15,22,29$, and $57 \mathrm{~d}$.

tively, throughout the experiment (Peters et al. 2005b). The number of nematode species found on an individual tile ranged from 1 to 10 (Fig. 5A). The maximum number of species on a single replicate stone of the natural hard substrates was $13 . \mathrm{H}^{\prime}$ and $\mathrm{J}^{\prime}$ for nematode species strongly increased during the

Fig. 2. Mean ( \pm 1 SE) meiofaunal abundance (A), and relative abundance of meiofaunal taxonomic groups on control (B) and elevated (C) experimental substrates after 2, $4,6,8,15,22,29$, and $57 \mathrm{~d}$.

first week, reached maximum (minimum for evenness) mean values on day 15 , and were maintained with some variation until day 57 (Fig. 5B, C).

Overall 5 species, Eumonhystera vulgaris (de Man, 1880), Chromadorina bioculata (Schultze in Carus, 1857), Eumonhystera filiformis (Bastian, 1865), Chromadorina viridis (Linstow, 1876), and Daptonema dubium (Büts- 


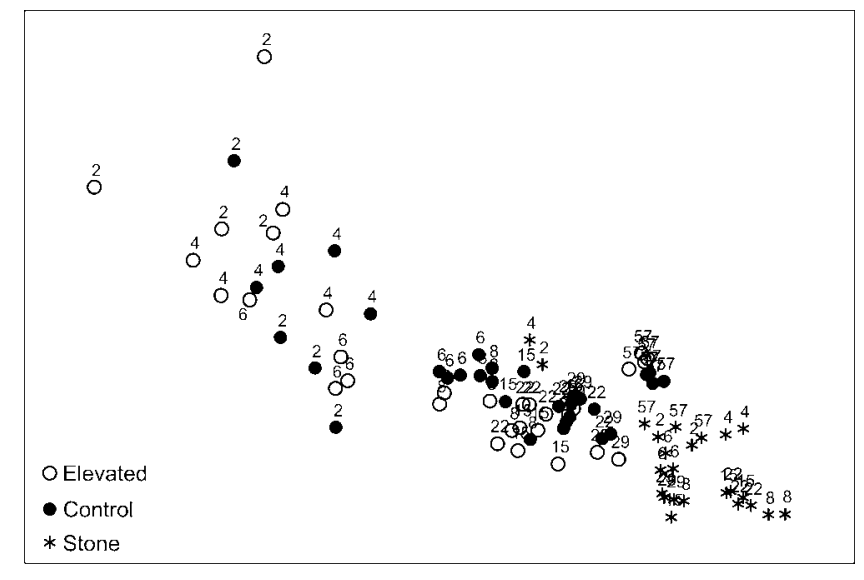

FIG. 3. Nonmetric multidimensional scaling (NMDS) plot (Stress $=0.04$ ) of meiofaunal taxonomic groups. Bray-Curtis similarity was calculated with $\sqrt{ }(\mathrm{x})$-transformed meiofaunal abundances from experimental substrates (control and elevated) and brush samples from natural hard substrates (stones). Numbers above symbols indicate sampling day.

chli, 1873), dominated the community after $8 \mathrm{~d}$ and accounted for most of the differences between treatments on the different sampling days. Eumonhystera vulgaris and C. bioculata were the most frequent species in both treatments and dominated the community numerically from day 6 onward (Peters et al. 2005b).

\section{Discussion}

\section{Periphyton development}

The general characteristics of periphyton community development in aquatic systems have been de-

TABLE 2. $R$ values from pairwise analysis of similarities tests (ANOSIM) for differences in meiofaunal group composition among sampling days (2-57, averaged across all treatment groups control and elevated plates). Global $R$ values from the 2-way crossed ANOSIM on experimental treatments (control and elevated plates) and sampling days $(2-57)$ were $R=0.322(p<0.001)$ and $R=0.712(p<0.001)$, respectively. Comparisons for consecutive sampling dates are in bold. ${ }^{*}=p<0.05,{ }^{* *}=p<0.01,{ }^{* * *}=\mathrm{p}<0.001$. n.s. $=$ not significant.

\begin{tabular}{|c|c|c|c|c|c|c|c|}
\hline \multirow[b]{2}{*}{ Day } & \multicolumn{7}{|c|}{ Day } \\
\hline & 2 & 4 & 6 & 8 & 15 & 22 & 29 \\
\hline 4 & $0.146^{\text {n.s. }}$ & & & & & & \\
\hline 6 & $0.661^{* * *}$ & $0.682^{* *}$ & & & & & \\
\hline 8 & $0.776^{* * *}$ & $1.000^{* *}$ & $0.620 * * *$ & & & & \\
\hline 15 & $0.870^{* * *}$ & $1.000^{* *}$ & $0.823^{* * *}$ & $0.318^{*}$ & & & \\
\hline 22 & $0.932^{* * *}$ & $1.000^{* *}$ & $1.000^{* * * *}$ & $0.443^{*}$ & $0.276^{* *}$ & & \\
\hline 29 & $0.922^{* * *}$ & $1.000^{* *}$ & $1.000^{* * * *}$ & $0.693^{* * *}$ & $0.292^{*}$ & $0.161^{\text {n.s. }}$ & \\
\hline 57 & $0.948^{* *}$ & $1.000^{* *}$ & $1.000^{* * *}$ & $0.953^{* *}$ & $0.885^{* *}$ & $0.990^{* *}$ & $0.917^{* *}$ \\
\hline
\end{tabular}
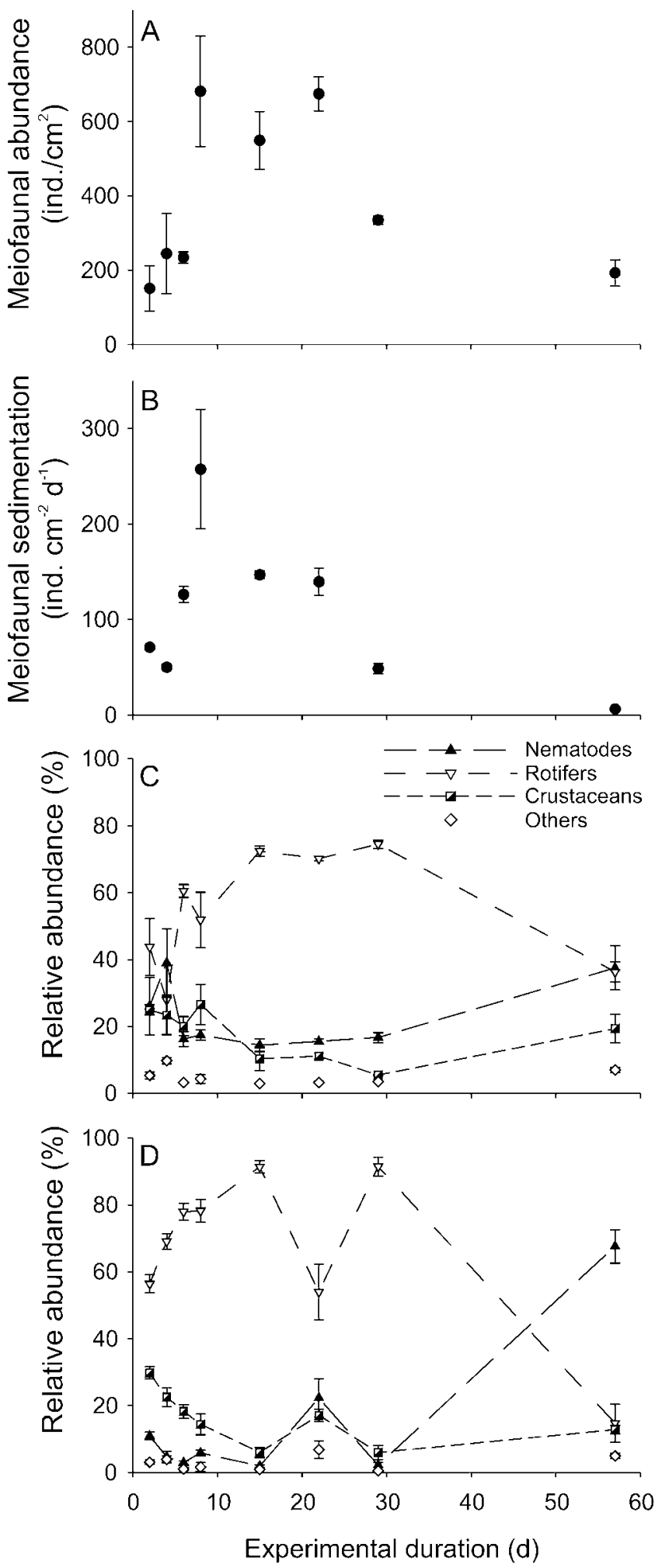

FIG. 4. Mean ( \pm 1 SE) meiofaunal abundance on natural substrate samples (A), sedimentation rates (B), and relative abundance of meiofaunal taxonomic groups on natural hard substrates (C) and in the sediment traps (D). 

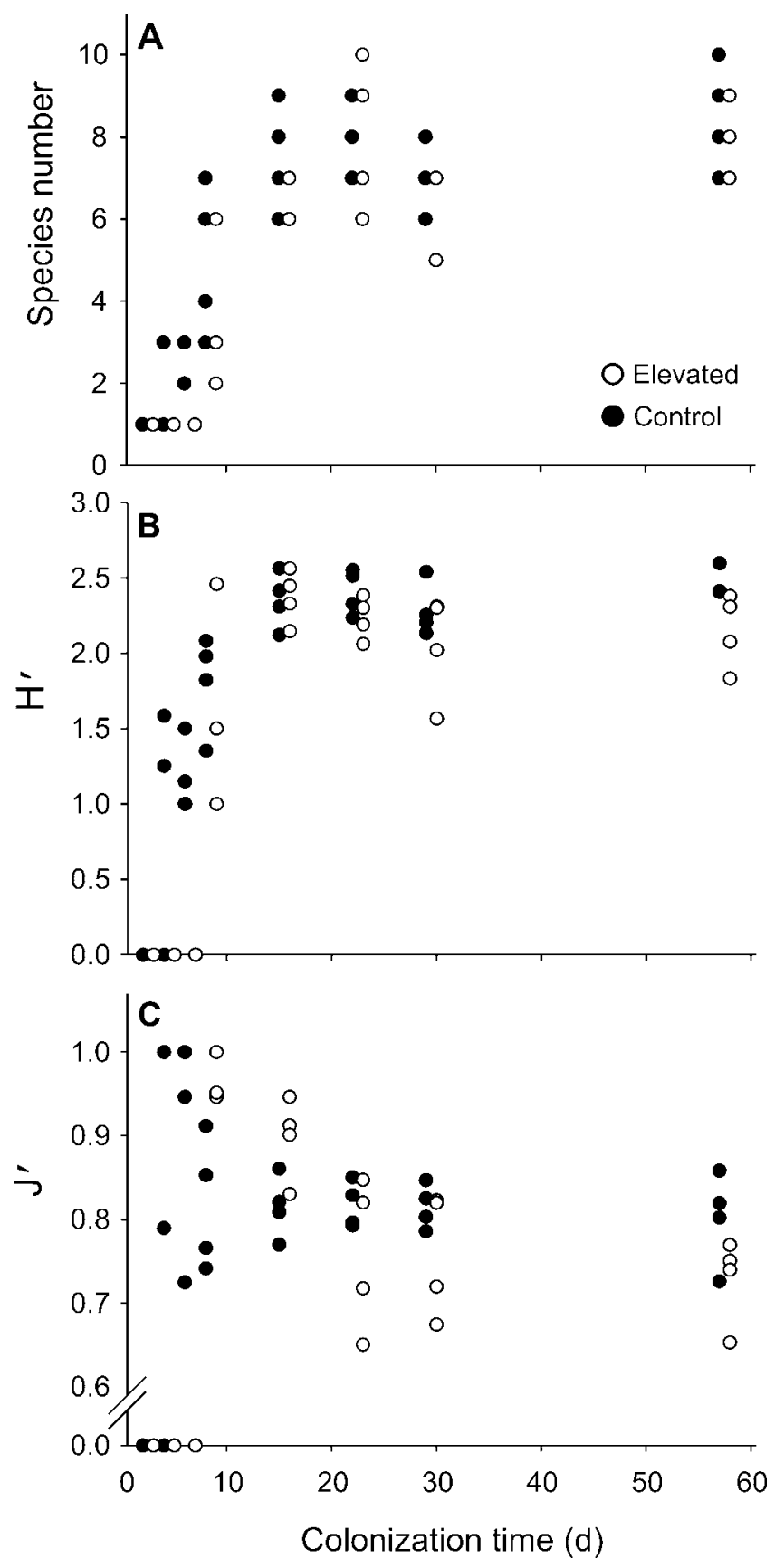

FIG. 5. Scatter plots of nematode species richness (A), Shannon-Wiener diversity $\left(\mathrm{H}^{\prime}\right)(\mathrm{B})$, and Pielou's evenness $\left(\mathrm{J}^{\prime}\right)$ after 2, 4, 6, 8, 15, 22, 29, and $57 \mathrm{~d}$ on control and elevated experimental substrates.

scribed in many studies (e.g., Brown and Austin 1973, Hudon and Bourget 1981, Hoagland et al. 1982, Johnson et al. 1997). An initial phase of bacterial colonization is followed by an exponential increase of algal biomass and a subsequent stationary phase. In our study, periphyton developed slowly with increasing algal biomass and organic matter content during the first $4 \mathrm{wk}$, and this phase was followed by a phase with higher growth rates. As shown in previous studies on benthic communities in streams (Stevenson 1984, Stevenson and Peterson 1991) and lakes (Hoagland et al. 1986), dispersal of organisms (bacteria, algae, protozoa) and other organic material (e.g., detritus) by water-column transport can be considered a key event in the colonization processes. In their study of colonization pathways in a lake, Hoagland et al. (1986) found that transport and dispersal of diatom cells through the water column was the most important factor for recolonization of littoral hard substrates. We regard the similar development of periphyton biomass in both treatments in our study as evidence for the importance of water-column transport in Lake Constance.

The development of a diverse and well developed periphyton mat might be an important prerequisite for the successful settlement and establishment of meiofaunal organisms because the periphyton functions as both food (Borchardt and Bott 1995, Montagna 1995, Bott and Borchardt 1999) and habitat (Peters and Traunspurger 2005) for meiofauna. Soft sediments, by their nature, offer a 3-dimensional habitat structure to colonizing organisms, but more-or-less bare hard substrates do not. Therefore, hard substrates must be precolonized by other periphyton components (algae, coarse particulate organic matter) to build a 3dimensional habitat for meiofauna. Habitat size, and probably habitat structure/complexity, will increase as periphyton biomass increases with ongoing colonization of substrates.

Describing and measuring habitat space/size is problematic for epilithic habitats. Habitat size can be estimated indirectly by measuring the biomass accumulated on hard-substrate surfaces. Previous investigations revealed positive correlations between epilithic meiofaunal abundance and periphyton biomass (chlorophyll $a$, algal biovolume) on natural hard substrates in lake littoral zones (Peters and Traunspurger 2005) and marine environments (Nagle 1968, Novak 1982, Hall and Bell 1988). A positive correlation between periphyton biomass and periphyton mat thickness at the study site used by Peters and Traunspurger (2005) showed that periphyton biomass is a good estimator of habitat size (LP and M. Hamitou, Limnological Institute, University of Konstanz, unpublished data).

\section{Meiofaunal colonization pathways}

The mode of access to new habitats is an important process for colonization. For meiofauna, this process has been investigated only in lotic freshwater (Palmer 1992, Robertson 2002) and marine systems (Sherman 
and Coull 1980, Chandler and Fleeger 1983, Palmer 1988). Our experiment revealed that dispersal through the water column is the main colonization pathway for epilithic meiofaunal organisms in a lake littoral zone because meiofaunal abundance and community development were similar on both treatments. This colonization pathway strongly depends on the number of organisms dispersed by drift through the water column and, therefore, will be indirectly dependent on the community structure and abundance of the species pool. The abundance and composition of the species in the ambient species pool also is an important determinant of the composition of the colonizing community, which should mirror the composition of the species pool, albeit not until later phases of colonization. The positive correlation between meiofaunal sedimentation rates and abundance in the species pool on natural hard substrates and the similar community composition of meiofauna groups in the traps and on natural hard substrates strongly supports this conclusion. Thus, water-column transport must be regarded as an intermediary step between a presence on source substrates and colonization of target substrates.

Based on the above conclusion, it follows that erosion or emergence of meiofaunal organisms from source substrates into the water column are the main factors influencing epilithic meiofaunal dispersal. Erosion and emergence depend on the magnitude of disturbance (Hagerman and Rieger 1981) and on the ability of meiofaunal organisms to persist on or to emerge from source substrates. For example, benthic copepods are generally good swimmers (Fleeger et al. 1995, Galassi et al. 2002) and, therefore, may act as active colonizers. Chandler and Fleeger (1983) reported that benthic copepods completely and rapidly recolonized sediments by suspended transport, whereas nematodes dispersed equally well by water-column drift and active movement through the sediment. Ullberg and Ólafsson (2003) found that nematodes are not subject only to passive transport, but also are able to choose habitat actively when suspended in the water column. Dispersal of meiofaunal organisms by active movement through the substrate might be easier in soft sediments than on hard substrates because the soft sediments are homogeneous and can be easily perambulated by meiofauna. In contrast, lake littoral zones frequently are characterized by large heterogeneous cobblestone areas that often lack direct contact between the overgrown surfaces of single stones ( $\mathrm{L}$. Peters, personal observation). This heterogeneity might make colonization of hard substrates by direct colonization (e.g., crawling) very difficult and, therefore, underlines the importance of water-column transport of meiofauna for their long- or short-distance dispersal in hard-bottom littoral zones of lakes.

\section{Meiofaunal colonization}

Meiofauna are an abundant group within epilithic communities (Peters and Traunspurger 2005) and potentially play an important ecological role in the periphyton, as has been revealed in soft sediments of other freshwater ecosystems (e.g., Hakenkamp and Morin 2000, Robertson 2000, Schmid-Araya and Schmid 2000). These organisms are typically good colonizers (Boulton et al. 1991, Palmer et al. 1992, Atilla and Fleeger 2000, Robertson 2000, da FonsecaGenevois et al. 2006), whose colonization success depends on the distance between the species pool and the target substrates (Coull and Palmer 1984). In our experiment, meiofauna colonized the experimental substrates quickly, and abundance increased significantly during the experiment (up to 106 ind. $/ \mathrm{cm}^{2}$ ). However, meiofaunal abundance did not reach values found on natural hard substrates (up to 681 ind. $/ \mathrm{cm}^{2}$ ). This result might be explained by lower periphyton biomass (i.e., habitat size) or simpler periphyton structure on the artificial substrates than on natural substrates. It might also be a consequence of the short colonization time for both periphyton and meiofaunal organisms.

Substrate surfaces in both treatments initially lacked attached organic and inorganic material. When the required periphyton habitat size becomes available in later colonization phases and the number of possible microniches (space or resources) is large, then meiofaunal organisms can persist in the periphyton and establish a diverse community. This result was illustrated by the development of nematode diversity on the experimental substrates (Peters et al. 2005b). The nematode community developed rapidly, with relatively high diversity values even after $8 \mathrm{~d}$, and maximum diversity after $2 \mathrm{wk}$ of colonization. This potentially essential dependency of meiofaunal diversity on periphyton development also is likely to explain the lower meiofaunal abundance on the experimental substrates than on natural substrates and the large variation among replicates. However, group composition of the meiofaunal community on experimental substrates became more similar to the ambient community on natural substrate in the littoral zone with time. This pattern of temporal development clearly indicates a high colonization ability of meiofaunal organisms and adaptability to changing habitat conditions.

In conclusion, our study represents the first investigation of the development of an epilithic meiofaunal 
community in a lake and the extent to which such a community is influenced by the colonization pathway and the habitat structure. Our results revealed the ability of meiofauna to arrive quickly in new habitats and to colonize stony substrates successfully even without pelagic larval stages. Meiofauna dispersed to hard substrates in the lake littoral zone through the water column, confirming meiofaunal dispersal mechanisms that have been observed in soft sediments. Evidence for the functional importance of meiofauna comes from soft sediment studies. We think that epilithic meiofauna also are functionally important for internal processes of the periphyton on hard substrates because these organisms are always present in high abundances. Meiofaunal organisms in freshwater ecosystems have been widely neglected in the past, and far more attention is needed to gain evidence for their importance in such habitats.

\section{Acknowledgements}

We thank A. Meduna for assistance in the field and B. Beese for chlorophyll $a$ analysis. Two anonymous referees gave helpful comments that improved the manuscript considerably. This study was supported by the German Research Foundation (DFG) within the Collaborative Research Centre 454 Littoral Zone of Lake Constance.

\section{Literature Cited}

Atilla, N., AND J. W. Fleeger. 2000. Meiofaunal colonization of artificial substrates in an estuarine embayment. Marine Ecology 21:69-83.

BARTON, D. R., AND J. C. H. CARTER. 1982. Shallow-water epilithic invertebrate communities of eastern Georgian Bay, Ontario, in relation to exposure to wave action. Canadian Journal of Zoology 60:984-993.

BäUerle, E., D. Ollinger, And J. Ilmberger. 1998. Some meteorological, hydrological, and hydrodynamical aspects of Upper Lake Constance. Archiv für Hydrobiologie Special Issues Advances in Limnology 53:31-83.

BorChaRDT, M. A., AND T. L. BOTT. 1995. Meiofaunal grazing of bacteria and algae in a Piedmont Stream. Journal of the North American Benthological Society 14:278-298.

BotT, T. L., AND M. A. BorchardT. 1999. Grazing of protozoa, bacteria, and diatoms by meiofauna in lotic epibenthic communities. Journal of the North American Benthological Society 18:499-513.

Boulton, A. J., S. E. Stibbe, N. B. Grimm, And S. G. Fisher. 1991. Invertebrate recolonization of small patches of defaunated hyporheic sediments in a Sonoran desert stream. Freshwater Biology 26:267-277.

Brown, S. D., AND A. P. Austin. 1973. Diatom succession and interaction in littoral periphyton and plankton. Hydrobiologia 43:333-356.

Chandler, G. T., And J. W. Fleeger. 1983. Meiofaunal colonization of azoic estuarine sediment in Louisianamechanisms of dispersal. Journal of Experimental Marine Biology and Ecology 69:175-188.

Clarke, K. R. 1993. Nonparametric multivariate analyses of changes in community structure. Australian Journal of Ecology 18:117-143.

Clarke, K. R., and R. H. Green. 1988. Statistical design and analysis for a "biological effects" study. Marine Ecology Progress Series 46:213-226.

Clarke, K. R., AND R. M. WARWICK. 2001. Changes in marine communities: an approach to statistical analysis and interpretation. PRIMER-E, Plymouth, UK.

Clarke, K. R., R. M. Warwick, and B. E. Brown. 1993. An index showing breakdown of seriation, related to disturbance, in a coral-reef assemblage. Marine Ecology Progress Series 102:153-160.

Colangelo, M. A., And V. U. Ceccherelli. 1994. Meiofaunal recolonization of azoic sediment in a Po-delta lagoon (Sacca-Di-Goro). Bollettino Di Zoologia 61:335-342.

Connell, J. H., and R. O. Slatyer. 1977. Mechanisms of succession in natural communities and their role in community stability and organization. American Naturalist 111:1119-1144.

Coull, B. C., AND M. A. PAlmer. 1984. Field experimentation in meiofaunal ecology. Hydrobiologia 118:1-19.

da Fonseca-Genevois, V., P. J. Somerfield, M. H. B. Neves, R. Coutinho, And T. Moens. 2006. Colonization and early succession on artificial hard substrata by meiofauna. Marine Biology 148:1039-1050.

Dall, P. C., C. LindegaARd, E. Jónsson, G. JónNSSON, And P. M. JÓNASSON. 1984. Invertebrate communities and their environment in the exposed littoral zone of Lake Esrom, Denmark. Archiv für Hydrobiologie Supplement 69:477524.

DiCKMAN, M. 1974. Changes in periphyton community structure following diatom inhibition. Oikos 25:187-193.

Duft, M., K. Fittkau, and W. Traunspurger. 2002. Colonization of exclosures in a Costa Rican stream: effects of macrobenthos on meiobenthos and the nematode community. Journal of Freshwater Ecology 17:531-541.

Eskin, R. A., AND M. A. PAlmer. 1985. Suspension of marine nematodes in a turbulent tidal creek: species patterns. Biological Bulletin 169:615-623.

FEGLEY, S. R. 1988. A comparison of meiofaunal settlement onto the sediment surface and recolonization of defaunated sandy sediment. Journal of Experimental Marine Biology and Ecology 123:97-113.

Feminella, J. W., AND C. P. HaWkins. 1995. Interactions between stream herbivores and periphyton: a quantitative analysis of past experiments. Journal of the North American Benthological Society 14:465-509.

Fleeger, J. W., P. O. Yund, And B. Sun. 1995. Active and passive processes associated with initial settlement and postsettlement dispersal of suspended meiobenthic copepods. Journal of Marine Research 53:609-645.

Galassi, D., P. Marmonier, M. J. Dole-Olivier, and S. D. RundLE. 2002. Microcrustacea. Pages 135-175 in S. D. Rundle, A. Robertson, and J. M. Schmid-Araya (editors). 
Freshwater meiofauna. Backhuys Publishers, Leiden, The Netherlands.

GARDNER, W. D. 1979a. Field assessment of sediment traps. Journal of Marine Research 38:41-52.

GARDNER, W. D. 1979b. Sediment trap dynamics and calibration: a laboratory evaluation. Journal of Marine Research 38:17-39.

Hagerman, G. M., AND R. M. Rieger. 1981. Dispersal of benthic meiofauna by wave and current action in Bogue Sound, North Carolina, USA. Marine Ecology 2:245-270.

Hakenkamp, C. C., AND A. Morin. 2000. The importance of meiofauna to lotic ecosystem functioning. Freshwater Biology 44:165-175.

Hall, M. O., AND S. S. Bell. 1988. Response of small motile epifauna to complexity of epiphytic algae on seagrass blades. Journal of Marine Research 46:613-630.

Hillebrand, H. 2002. Top-down versus bottom-up control of autotrophic biomass-a meta-analysis on experiments with periphyton. Journal of the North American Benthological Society 21:349-369.

Hillebrand, H., AND M. Kahlert. 2001. Effect of grazing and nutrient supply on periphyton biomass and nutrient stoichiometry in habitats of different productivity. Limnology and Oceanography 46:1881-1898.

Hillebrand, H., M. Kahlert, A.-L. Haglund, U. Berninger, S. NAGEL, AND S. WiCKHAM. 2002. Control of microbenthic communities by grazing and nutrient supply. Ecology 83: 2205-2219.

Hoagland, K. D. 1983. Short-term standing crop and diversity of periphytic diatoms in a eutrophic reservoir. Journal of Phycology 19:30-38.

Hoagland, K. D., S. C. Roemer, and J. R. Rosowski. 1982. Colonization and community structure of 2 periphyton assemblages, with emphasis on the diatoms (Bacillariophyceae). American Journal of Botany 69:188-213.

Hoagland, K. D., A. Zlotsky, and C. G. Peterson. 1986. The source of algal colonizers on rock substrates in a freshwater impoundment. Pages 21-39 in L. V. Evans and K. D. Hoagland (editors). Algal biofouling. Elsevier Science Publishing, Amsterdam, The Netherlands.

Hudon, C., AND E. Bourget. 1981. Initial colonization of artificial substrate: community development and structure studied by scanning electron-microscopy. Canadian Journal of Fisheries and Aquatic Sciences 38:1371-1384.

Jensen, P. 1981. Phyto-chemical sensitivity and swimming behavior of the free-living marine nematode Chromadorita tenuis. Marine Ecology Progress Series 4:203-206.

Johnson, R. E., N. C. Tuchman, and C. G. Peterson. 1997. Changes in the vertical microdistribution of diatoms within a developing periphyton mat. Journal of the North American Benthological Society 16:503-519.

KAIRESALO, T. 1976. Measurement of production of epilithiphyton and littoral plankton in Lake Pääjärvi, southern Finland. Annales Botanici Fennici 13:114-118.

KaIRESAlO, T. 1983. Dynamics of epiphytic communities on Equisetum fluviatile L.: response to short-term variation in environmental conditions. Pages 153-160 in R. G. Wetzel (editors). Periphyton of freshwater ecosystems. Dr W. Junk, The Hague, The Netherlands.
Lamberti, G. A., S. V. Gregory, C. P. Hawkins, R. C. Wildman, L. R. Ashkenas, and D. M. DeNicola. 1992. Plantherbivore interactions in streams near Mount St Helens. Freshwater Biology 27:237-247.

LAMBERTI, G. A., AND V. H. Resh. 1983. Stream periphyton and insect herbivores: an experimental study of grazing by a caddisfly population. Ecology 64:1124-1135.

Marker, A. F. H., E. A. Nusch, and B. Riemann. 1980. The measurement of photosynthetic pigment in freshwater and standardization of methods: conclusions and recommendations. Archiv für Hydrobiologie, Beiheft Ergebnisse der Limnologie 14:91-106.

Montagna, P. A. 1995. Rates of metazoan meiofaunal microbivory: a review. Vie et Milieu 45:1-9.

NAGLE, J. S. 1968. Distribution of epibiota of macroepibenthic plants. Contributions in Marine Science 13:105-144.

NovAK, R. 1982. Spatial and seasonal distribution of the meiofauna in the seagrass Posidonia oceanica. Netherlands Journal of Sea Research 16:380-388.

Nusch, E. A. 1980. Comparison of different methods for chlorophyll and phaeopigment determination. Archiv für Hydrobiologie 14:14-36.

PAlmer, M. A. 1988. Dispersal of marine meiofauna: a review and conceptual model explaining passive transport and active emergence with implications for recruitment. Marine Ecology Progress Series 48:81-91.

PALMER, M. A. 1992. Incorporating lotic meiofauna into our understanding of faunal transport processes. Limnology and Oceanography 37:329-341.

Palmer, M. A., A. E. Bely, And K. E. Berg. 1992. Response of invertebrates to lotic disturbance: a test of the hyporheic refuge hypothesis. Oecologia (Berlin) 89:182-194.

Palmer, M. A., And G. Gust. 1985. Dispersal of meiofauna in a turbulent tidal creek. Journal of Marine Research 43:179_ 210.

Peters, L., H. Hillebrand, and W. Traunspurger. 2007. Spatial variation of grazer effects on epilithic meiofauna and algae. Journal of the North American Benthological Society 26:78-91.

Peters, L., N. Scheifhacken, M. Kahlert, and K.-O. RothHAUPT. 2005a. An efficient in situ method for sampling periphyton in lakes and streams. Archiv für Hydrobiologie 163:133-141.

Peters, L., and W. Traunspurger. 2005. Species distribution of free-living nematodes and other meiofauna in littoral periphyton communities of lakes. Nematology 7:267280.

Peters, L., W. Traunspurger, M. A. Wetzel, and K.-O. Rothнаupt. 2005b. Community development of freeliving aquatic nematodes in littoral periphyton communities. Nematology 7:901-916.

Picket, S. T. A., AND P. S. White. 1985. The ecology of natural disturbance and patch dynamics. Academic Press, Orlando, Florida.

RoBERTSON, A. L. 2000. Lotic meiofaunal community dynamics: colonisation, resilience and persistence in a spatially and temporally heterogeneous environment. Freshwater Biology 44:135-147.

Robertson, A. L. 2002. Changing times: the temporal 
dynamics of freshwater benthic microcrustacea. Pages 261-294 in S. D. Rundle, A. Robertson, and J. M. SchmidAraya (editors). Freshwater meiofauna. Backhuys Publishers, Leiden, The Netherlands.

Roemer, S. C., K. D. Hoagland, and J. R. Rosowski. 1984. Development of a fresh-water periphyton community as influenced by diatom mucilages. Canadian Journal of Botany 62:1799-1813.

Schmid-Araya, J. M., and P. E. Schmid. 2000. Trophic relationships: integrating meiofauna into a realistic benthic food web. Freshwater Biology 44:149-163.

SEINHORST, J. W. 1959. A rapid method for the transfer of nematodes from fixative to anhydrous glycerin. Nematologica 4:67-69.

SEINHORST, J. W. 1962. On the killing, fixation and transferring to glycerin of nematodes. Nematologica 8:29-32.

Sherman, K. M., and B. C. Coull. 1980. The response of meiofauna to sediment disturbance. Journal of Experimental Marine Biology and Ecology 46:59-71.

Sherman, K. M., J. A. Reidenauer, D. Thistle, and D. Meeter. 1983. Role of a natural disturbance in an assemblage of marine free-living nematodes. Marine Ecology Progress Series 11:23-30.

Stevenson, R. J. 1984. How currents on different sides of substrates in streams affect mechanisms of benthic algal accumulation. Internationale Revue der gesamten Hydrobiologie 69:241-262.

Stevenson, R. J., and C. G. Peterson. 1991. Emigration and immigration can be important determinants of benthic diatom assemblages in streams. Freshwater Biology 26: 279-294.

STICH, H. B., AND A. BRINKER. 2005. Less is better: uncorrected versus pheopigment corrected photometric chlorophyll-a estimation. Archiv für Hydrobiologie 162:111-120.

Sun, B., and J. W. Fleegerr. 1994. Field experiments on the colonization of meiofauna into sediment depressions. Marine Ecology Progress Series 110:167-175.

TRAunspurger, W. 1992. A study of free-living freshwater nematodes of hard substrates in the littoral of the oligotrophic Königssee (National Park Berchtesgaden, FRG). Spixiana 15:233-238.

UllberG, J., and E. Ólafsson. 2003. Free-living marine nematodes actively choose habitat when descending from the water column. Marine Ecology Progress Series 260:141-149.

Vadeboncoeur, Y., and A. D. Steinman. 2002. Periphyton function in lake ecosystems. TheScientificWorld 2:14491468.

WARWICK, R. M., AND J. M. GEE. 1984. Community structure of estuarine meiobenthos. Marine Ecology Progress Series 18:97-111.

Wetzel, M. A., A. Weber, AND O. Giere. 2002. Re-colonization of anoxic/sulfidic sediments by marine nematodes after experimental removal of macroalgal cover. Marine Biology 141:679-689.

Witthöft-Mühlmann, A., W. Traunspurger, and K.-O. RothHAUPT. 2005. Meiobenthic response to river-borne benthic particulate matter-a microcosm experiment. Freshwater Biology 50:1548-1559.

YounG, O. W. 1945. A limnological investigation of periphyton in Douglas Lake, Michigan. Transactions of the American Microscopical Society 64:1-20. 